\title{
A reflection on Construction Mediation in Scotland
}

\section{Introduction}

This paper reflects upon research undertaken by the authors over recent years analysing the views and experiences of both lawyers and end-users (contractors and sub-contractors) relative to construction mediation in Scotland (Agapiou and Clark, 2011; Agapiou and Clark, 2012; Agapiou and Clark, 2013). Although research into construction mediation could be found in many other jurisdictions such as England and Wales (Gould, 1999; Gould et al, 2009), the USA, South Africa, and Australia (for a review of international evidence see Brooker and Wilkinson, 2010), the aim of our recent work was to fill a gap in the existing literature and shed significant new light on the use of, and attitudes towards construction mediation in Scotland.

The purpose of this paper is to compare and contrast data arising from the two groups of research subjects in respect of their views on, and experiences of the mediation process and explore some of the reasons why such differences exist. While most research in the mediation field (At least outside of court-annexed mediation programmes ) has tended to focus on the views and experience of lawyers, the findings presented here are useful in helping us understand the different ways in which mediation and indeed dispute resolution more generally is perceived and encountered by both end-users and their lawyers.

In this sense, there has been much debate and discussion on the role that lawyers should play in the mediation process (Reich 2002; Clark 2012). It is widely recognised that the increasing involvement of lawyers can affect the way in which mediation is conducted, the lawyer-client power balance and the perception of the process itself (Wissler, 2003). It is also widely documented that the practice of mediation is affected by the way lawyers perceive and utilise it, such that they are commonly referred to as gatekeepers to the process (Welsh, 2004). Indeed, a growing body of research demonstrates that lawyers often control which disputes are mediated, the choice of mediator, and the prioritisation of interests within the process itself (see generally Clark, 2012). If we accept that lawyers' perceptions \& values influence the ability of mediation to deliver potential benefits, then it follows that lawyers' interests need to be taken into account for mediation to be more widely adopted as a favoured means of dispute resolution; notwithstanding lawyers' interests can often diverge from those of their clients (Sela, 2009; Clark 2012, chpt 3). In terms of these interests, there is a significant amount of scholarship focusing on the ways in which lawyers reframe and edit disputes into a legal form that they best understand with the matter then entering a familiar, legal-centric process which ultimately produces outcomes limited by law (Felstiner and Sarat 1980-81). Mediation represents a challenge to this dominant model and may be viewed with suspicion as a result. We explore some of these issues more fully through the data analysis below.

\section{Methods}

The research strategy combined both quantitative and qualitative research methods. This analysis articulated here draws on questionnaire survey and interview research carried out between 2010 and 2012. The method of data collection \& analysis comprised two stages phases, involving both Construction Lawyers \& Construction Contractors \& Sub-Contractors:

The first stage involved the distribution of a questionnaire survey of 165 Scottish construction lawyers with a response rate of c. 30\% (50 respondents), followed by a qualitative approach to produce 'thicker' descriptions (Geertz, 1973) of salient issues relative to construction lawyers' interaction with construction mediation, drawing upon semistructured, face-to-face interviews of participants. 
The 11 interviewees were from various positions within the legal profession including Advocates, Solicitors and Solicitor-Advocates lasting on average around an hour. We attempted to track all contentious construction lawyers in Scotland.

In Stage Two a questionnaire survey was deployed to elicit the opinion of end-users and potential end-users relative to mediation based upon a sample of main and sub-contracting firms in Scotland. Using a membership list of contractors and subcontractors provided by the Scottish Building Federation (SBF), comprising mainly small and medium sized construction firms, we collected responses from 63 firms, representing a survey response rate of around $18 \%$. The findings of SBF questionnaire survey were subsequently discussed in semi-structured interviews with a panel of 9 industry experts.

In both cases, interview participants were recruited from those: (i) with prior experience of mediation in the construction context; and (ii) respondents who had provided detailed comments on mediation in quantitative phase of enquiry. The interviewees were also geographically dispersed within the Central Belt. The qualitative phase of enquiry involved an interview with the each participant each lasting approximately one hour.

Whilst we are aware that the samples were small and inviting respondents to self-select for interview has its methodological weaknesses, we pursued this approach as it was the most effective way to obtain access to participants with experience of mediation in the construction context in Scotland.

All the interviews conducted in this research were recorded using a digital voice recorder and transcribed. Permission was sought from the participants to record the interviews. The audio files of all interviews were transcribed for the purposes of analysis. The statistical analysis of the quantitative survey data was undertaken using the SPSS software package. We used descriptive statistics to identify the existence of any patterns in the responses provided and to present a profile of the sample population.

The next section presents some of the key findings from the data analysis from the questionnaire and the participant interviews focusing on the views and experiences of lawyers and end users with respect to mediation.

Findings and Analysis

Knowledge of Mediation

All lawyers who responded to our survey professed awareness of mediation, compared to $80 \%$ of the end-users. Given the wealth of publicity and awareness raising in respect of mediation experienced in Scotland over recent years, the lawyer unanimity in terms of knowledge holds few surprises, although the research did not glean what kind of understanding lawyers held about the process. The fact that one in five end-users was still unaware of mediation is perhaps a little alarming. Additionally, we might surmise that a far greater percentage of those that did not respond to the survey may be largely unaware of the process. Of course lawyers as dispute resolution specialists would be expected to have higher awareness levels of new processes such as mediation than their clients.

Equally, however it is clear from the research that education and training provision, including CPD and on-going professional learning, has a significant role to play in expediting knowledge levels. Here there is a clear divergence between such exposure for lawyers and end-users. In our survey some $82 \%$ of lawyers had received training or education in mediation. This represents a significant increase from the $60 \%$ recorded in research into Scottish commercial lawyers' experiences of mediation undertaken around five years prior to this survey (Clark \& Dawson 2007). One of the starkest findings from the 2007 survey was 
that less than $4 \%$ of the commercial lawyers in the 2006 survey reported exposure to mediation in Law School. That figure rose to $20 \%$ in the current study, suggesting an increased embedding of mediation in Scottish traditional lawyer education. It is also clear from the lawyer research that CPD and on-going professional training and education in mediation for legal professionals has risen sharply in recent years.

While the educational picture is thus positive in respect of lawyers, clients generally lacked any training or education in mediation, with only $12 \%$ reporting any such exposure. Clearly respondents from the world of contractors and sub-contractors emanate from a whole range of professional and non-professional backgrounds which would at times militate against educational exposure to mediation in any initial training. A recurring them in interviews with end-users, however, pointed to deleterious impact of the dearth of ongoing professional training and education provided in mediation by professional bodies in the field such as RICS, Institute of Civil Engineers and Corporation of Architects. We shall return to the issue of education and training for end-users at the end of the paper.

\section{Mediation Use}

Lawyers were much more likely than clients to have instituted polices on mediation use. Some $66 \%$ of lawyers surveyed had a firm policy or practice of encouraging use of mediation, as opposed to only $19 \%$ of clients. This schism is to be expected perhaps, given that lawyers are repeat players in dispute resolution as opposed to the their clients, many of whom will have had much more limited exposure to formal disputing practices generally and may not formulate policies in respect of their occurrences.

The professed policy of many lawyers to encourage the use of mediation chimes with reports that many large law firms in Scotland have changed the name of their litigation departments to 'conflict resolution' hubs to reflect a more holistic approach to dispute resolution (Clark 2009). Nonetheless, it is difficult to determine how much store to put on such shifts in nomenclature or reported policies in favour of mediation use by lawyers, per se. Certainly our interviews with end users, found few reporting that lawyers were often in favour of mediation in the construction sector. Equally such a sentiment was at times expressed by lawyer respondents to our survey themselves smarting at the lack of receptivity towards the process from their legal colleagues. We explore these matters further below.

In the lawyers' survey some $58 \%$ of respondents had represented a client in mediation on at least one occasion. For end-users who responded, the rate of use of mediation was $30 \%$. The lawyer survey tracked 178 cases and revealed a settlement rate of $74 \%$ with a further $9 \%$ partially settling at mediation. The end-user survey uncovered only 37 cases with a lower settlement rate of $65 \%$ but with a further $14 \%$ partially settling. The disparity in the results in terms of volume may reflect the fact that our end-user based research was limited to the members of the Scottish Building Federation, and also stem from the more limited response rate to that survey. Equally, there may clearly be double counting in much of the lawyer reported cases which may have inflated the number reported. We might also surmise that some lawyer respondents at times referred to cases which fell outside true construction disputes and others may have been cross border in nature involving English end users. Nonetheless, there is a marked similarity in the types of cases commonly reported by lawyers and end-users as being mediated (such as change to scope of work, payment, damages, professional negligence and delay) and also similar reported settlement rates (particularly when partially settled cases are included). Importantly, there were also generally shared views in respect of high reported rates of satisfaction with mediation in terms of such factors as speed, cost, mediator performance and quality of outcomes. 
End users and lawyers also espoused generally similar reasons for mediating, such as saving costs and time, seeking continuation of business relationships, and to a lesser extent procuring creative agreements. Although the data from clients was generally too limited to make any concrete assertions in this respect, it is clear from the lawyer survey that although the overall numbers of construction litigators that have mediated may remain low, once they attempt the process they tend to become repeat players. It is striking to note that almost all lawyer respondents that had mediated had done so more than once. In this sense, there was also a statistically significant correlation between rate of lawyer usage and levels of satisfaction suggesting that either lawyers became more satisfied the more experienced they became in the process, or that the more content lawyers sought out repeat experiences.

Attitudes to Mediation

It is perhaps in relation to attitudes held in respect of mediation that most divergence between lawyers and their clients are to be found. Here we summarise some of the main issues uncovered. Tables 1 and 2 illustrate the breakdown of percentage response of Lawyers and End-Users' attitudes to mediation. First, on the matter of judicial prompting of mediation, although the extent that the process should become entwined with formal courts and formal civil justice mechanisms has long been a controversial issue (see Clark 2012, chap 5; Genn 2009), end-users were generally supportive of such measures. For instance, some $76 \%$ of end-users surveyed agreed that judges should refer more cases to mediation. The same proportion $(76 \%)$ went so far as to agree that rendering mediation a mandatory first step in litigation procedures was an attractive proposition.

Lawyers trod a little more cautiously on this territory. Nonetheless, $62 \%$ of lawyers surveyed were in favour of increased judicial promotion and a slim majority - 54\% - supported compelling recourse to mediation. Given that previous research into Scottish commercial lawyers found a mere $27 \%$ of lawyers supporting mandatory mediation (Clark and Dawson, 2007), the tide may be turning within legal circles on this issue - at least for those who have become converts to the process. The fact that end users were more supportive of institutional measures to help expedite the process may also be linked to a heavy perception of lawyer resistance to mediation as well as redolent of perceived barriers within the construction industry itself. These issues are articulated further below.

When and how lawyers ought to be involved in mediation are emotive and divisive issues. While $74 \%$ of lawyer respondents suggested that legal practitioners made the best mediators, this view was not shared by clients. A mere $4 \%$ of clients agreed with this proposition. By contrast, a whopping $88 \%$ of clients stated that those with industry experience as construction professionals were superior in the mediation role; which may include construction lawyers. Such matters tie into the longstanding debate regarding the identity of the rightful inheritors of the mediator's crown. While there is a significant and longstanding debate surrounding whether lawyers are the most appropriate professionals to act as mediators (Clark 2012, Ch.4), the extent that subject matter expertise in the area of dispute is an essential tool in the mediator's kit bag is also a moot issue (see Burns 2012). 
Table 1: Breakdown of percentage response of Lawyers' attitudes to mediation

\begin{tabular}{|c|c|c|c|c|c|}
\hline Attitudes & $\begin{array}{l}\text { Strongly } \\
\text { agree }\end{array}$ & $\begin{array}{l}\text { Somewhat } \\
\text { agree }\end{array}$ & $\begin{array}{l}\text { Somewhat } \\
\text { disagree }\end{array}$ & $\begin{array}{l}\text { Strongly } \\
\text { disagree }\end{array}$ & $\begin{array}{l}\text { Don't } \\
\text { know }\end{array}$ \\
\hline $\begin{array}{l}\text { If I participated more often in mediation my } \\
\text { standing amongst colleagues would suffer }\end{array}$ & $0 \%$ & $16 \%$ & $24 \%$ & $48 \%$ & $12 \%$ \\
\hline $\begin{array}{l}\text { Mediation is inappropriate where there is a power } \\
\text { imbalance between the parties }\end{array}$ & $8 \%$ & $52 \%$ & $20 \%$ & $16 \%$ & $4 \%$ \\
\hline Judges should refer more cases to mediation & $28 \%$ & $48 \%$ & $12 \%$ & $12 \%$ & $0 \%$ \\
\hline $\begin{array}{l}\text { Making mediation a mandatory first step in the } \\
\text { construction industry would be a positive } \\
\text { development }\end{array}$ & $24 \%$ & $52 \%$ & $16 \%$ & $8 \%$ & $0 \%$ \\
\hline Lawyers make the best mediators & $0 \%$ & $4 \%$ & $60 \%$ & $20 \%$ & $16 \%$ \\
\hline $\begin{array}{l}\text { Those with substantial knowledge of the area of } \\
\text { dispute make the best mediators }\end{array}$ & $36 \%$ & $52 \%$ & $4 \%$ & $4 \%$ & $4 \%$ \\
\hline $\begin{array}{l}\text { Litigation is generally well adapted to the needs } \\
\text { and practices of the construction community }\end{array}$ & $0 \%$ & $12 \%$ & $40 \%$ & $32 \%$ & $16 \%$ \\
\hline $\begin{array}{l}\text { Arbitration is generally well adapted to the needs } \\
\text { and practices of the construction community }\end{array}$ & $0 \%$ & $20 \%$ & $40 \%$ & $16 \%$ & $24 \%$ \\
\hline $\begin{array}{l}\text { Adjudication is generally well adapted to the needs } \\
\text { and practices of the construction community }\end{array}$ & $8.3 \%$ & $16.7 \%$ & $54.2 \%$ & $4.2 \%$ & $16.7 \%$ \\
\hline $\begin{array}{l}\text { Default to adjudication in many construction } \\
\text { disputes renders mediation obsolete }\end{array}$ & $0 \%$ & $41.7 \%$ & $29.2 \%$ & $8.3 \%$ & $20.8 \%$ \\
\hline Mediation suffers from a lack of coercive power & $4.3 \%$ & $47.8 \%$ & $21.7 \%$ & $17.4 \%$ & $8.7 \%$ \\
\hline $\begin{array}{l}\text { Mediation is an opportunity for lawyers to offer } \\
\text { further services to their clients }\end{array}$ & $8.7 \%$ & $52.2 \%$ & $20.8 \%$ & $25 \%$ & $16.7 \%$ \\
\hline Lawyers will lose money if mediation grows & $0 \%$ & $37.5 \%$ & $46 \%$ & $32 \%$ & $16 \%$ \\
\hline $\begin{array}{l}\text { Suggesting mediation to an opponent is a sign of } \\
\text { weakness }\end{array}$ & $0 \%$ & $12.5 \%$ & $41.7 \%$ & $41.7 \%$ & $4.2 \%$ \\
\hline $\begin{array}{l}\text { Construction contracts should contain a mediation } \\
\text { clause }\end{array}$ & $8.3 \%$ & $62.5 \%$ & $20.8 \%$ & $4.2 \%$ & $4.2 \%$ \\
\hline $\begin{array}{l}\text { A barrier to mediation's development in Scotland is } \\
\text { its negative perception among construction } \\
\text { industry participants }\end{array}$ & $8.3 \%$ & $41.7 \%$ & $25 \%$ & $8.3 \%$ & $16.7 \%$ \\
\hline $\begin{array}{l}\text { A barrier to mediation's development in Scotland is } \\
\text { its negative perception among lawyers }\end{array}$ & $4.2 \%$ & $37.5 \%$ & $20.8 \%$ & $12.5 \%$ & $25 \%$ \\
\hline $\begin{array}{l}\text { Mediation training should be compulsory for } \\
\text { lawyers }\end{array}$ & $12.5 \%$ & $45.8 \%$ & $20.8 \%$ & $8.3 \%$ & $12.5 \%$ \\
\hline $\begin{array}{l}\text { There is a lack of awareness regarding mediation } \\
\text { amongst the legal fraternity in Scotland }\end{array}$ & $4.3 \%$ & $39.1 \%$ & $21.7 \%$ & $4.3 \%$ & $30.4 \%$ \\
\hline $\begin{array}{l}\text { There is a lack of awareness regarding mediation } \\
\text { amongst the Scottish construction industry }\end{array}$ & $16.7 \%$ & $45.8 \%$ & $16.7 \%$ & $8.3 \%$ & $12.5 \%$ \\
\hline Mediation is of more utility in low value disputes & $4.2 \%$ & $29.2 \%$ & $41.7 \%$ & $16.7 \%$ & $8.3 \%$ \\
\hline $\begin{array}{l}\text { Mediators should offer their opinion on the merits } \\
\text { of the dispute before them to the parties involved }\end{array}$ & $12.5 \%$ & $33.3 \%$ & $25 \%$ & $8.3 \%$ & $20.8 \%$ \\
\hline
\end{tabular}


Table 2: Breakdown of percentage response of End-Users' attitudes to mediation

\begin{tabular}{|c|c|c|c|c|c|}
\hline Attitudes & $\begin{array}{l}\text { Strongly } \\
\text { agree }\end{array}$ & $\begin{array}{l}\text { Somewhat } \\
\text { agree }\end{array}$ & $\begin{array}{l}\text { Somewhat } \\
\text { disagree }\end{array}$ & $\begin{array}{l}\text { Strongly } \\
\text { disagree }\end{array}$ & $\begin{array}{l}\text { Don't } \\
\text { know }\end{array}$ \\
\hline $\begin{array}{l}\text { If a lawyer participated more often in mediation } \\
\text { his/her standing amongst colleagues would suffer }\end{array}$ & $0 \%$ & $2 \%$ & $22 \%$ & $74 \%$ & $2 \%$ \\
\hline $\begin{array}{l}\text { Mediation is detrimental to the development of } \\
\text { law }\end{array}$ & $6 \%$ & $38 \%$ & $26 \%$ & $24 \%$ & $6 \%$ \\
\hline $\begin{array}{l}\text { Mediation is inappropriate where there is a power } \\
\text { imbalance between the parties }\end{array}$ & $2 \%$ & $16 \%$ & $54 \%$ & $26 \%$ & $2 \%$ \\
\hline Judges should refer more cases to mediation & $4 \%$ & $52 \%$ & $10 \%$ & $24 \%$ & $10 \%$ \\
\hline $\begin{array}{l}\text { Making mediation a mandatory first step would be } \\
\text { a positive development }\end{array}$ & $4 \%$ & $40 \%$ & $14 \%$ & $32 \%$ & $10 \%$ \\
\hline Legal practitioners make the best mediators & $2 \%$ & $32 \%$ & $42 \%$ & $2 \%$ & $22 \%$ \\
\hline $\begin{array}{l}\text { Litigation is generally well adapted to the needs } \\
\text { and practices of the construction community }\end{array}$ & $4 \%$ & $32 \%$ & $46 \%$ & $18 \%$ & $0 \%$ \\
\hline $\begin{array}{l}\text { Arbitration is generally well adapted to the needs } \\
\text { and practices of the construction community }\end{array}$ & $2 \%$ & $16 \%$ & $46 \%$ & $34 \%$ & $2 \%$ \\
\hline $\begin{array}{l}\text { Adjudication is generally well adapted to the } \\
\text { needs and practices of the construction } \\
\text { community }\end{array}$ & $24 \%$ & $60 \%$ & $14 \%$ & $2 \%$ & $0 \%$ \\
\hline $\begin{array}{l}\text { Default to adjudication in many construction } \\
\text { disputes renders mediation obsolete }\end{array}$ & $0 \%$ & $34 \%$ & $34 \%$ & $28 \%$ & $4 \%$ \\
\hline Mediation suffers from a lack of coercive power & $2 \%$ & $24 \%$ & $40 \%$ & $28 \%$ & $6 \%$ \\
\hline $\begin{array}{l}\text { Mediation is an opportunity for lawyers to offer } \\
\text { further services to their clients }\end{array}$ & $22 \%$ & $66 \%$ & $4 \%$ & $4 \%$ & $4 \%$ \\
\hline Lawyers will lose money if mediation grows & $0 \%$ & $6 \%$ & $46 \%$ & $32 \%$ & $16 \%$ \\
\hline $\begin{array}{l}\text { Suggesting mediation to an opponent is a sign of } \\
\text { weakness }\end{array}$ & $0 \%$ & $2 \%$ & $40 \%$ & $52 \%$ & $6 \%$ \\
\hline $\begin{array}{l}\text { Construction contracts should contain a } \\
\text { mediation clause }\end{array}$ & $12 \%$ & $50 \%$ & $18 \%$ & $10 \%$ & $10 \%$ \\
\hline $\begin{array}{l}\text { A barrier to mediation's development in Scotland } \\
\text { is its negative perception among clients }\end{array}$ & $4 \%$ & $34 \%$ & $30 \%$ & $8 \%$ & $24 \%$ \\
\hline $\begin{array}{l}\text { A barrier to mediation's development in Scotland } \\
\text { is its negative perception among lawyers }\end{array}$ & $2 \%$ & $24 \%$ & $52 \%$ & $10 \%$ & $12 \%$ \\
\hline $\begin{array}{l}\text { Mediation training should be compulsory for } \\
\text { lawyers }\end{array}$ & $18 \%$ & $34 \%$ & $28 \%$ & $10 \%$ & $10 \%$ \\
\hline $\begin{array}{l}\text { There is a lack of awareness regarding mediation } \\
\text { amongst the legal fraternity in Scotland }\end{array}$ & $2 \%$ & $42 \%$ & $34 \%$ & $10 \%$ & $12 \%$ \\
\hline Mediation is of more utility in low value disputes & $2 \%$ & $8 \%$ & $40 \%$ & $38 \%$ & $12 \%$ \\
\hline
\end{tabular}


True facilitative mediators would argue that subject expertise is irrelevant and that core mediation skills, attributes and experience are the most salient requirements. Nonetheless, it is hardly surprising that construction professionals, used as they are to adjudicators with significant subject matter expertise, should demand the same from their mediators. Such mediators would be able to bring industry norms and technical know-how into the mix which may be seen as valuable selling points.

One matter that affects the extent that mediation is adopted is of course the appeal of other options for disposing disputes that lie on the table. In this sense, it can be contended that one of the key roadblocks to mediation development in the construction sector in the UK is the dominant position of statutory adjudication as a default dispute resolution process in most construction contracts. Since its championing by the Latham Report in 1994 (Latham 1994) adjudication has gained industry acceptance as the usual manner by which a binding (albeit temporary) resolution to disputes for which negotiations have proved incapable of settling can be gained. Our survey suggests that construction lawyers in particular have lined up to support the process in their droves. While the vast majority of lawyer respondents were disparaging about litigation and arbitration, some $84 \%$ agreed with the statement that "adjudication is generally well adapted to the needs of the construction industry". It should be noted that the survey was conducted prior to enactment of the Arbitration (Scotland) Act which may have improved matters in this regard (see Dundas and Bartos, 2010)

Furthermore, in interviews, the majority of lawyers waxed lyrical about adjudication and generally viewed the process as the dominant and obvious next step to resolving disputes for which negotiations had failed to produce a settlement. Interviewees referred to such positive features of adjudication as getting a quick and binding decision, the relatively low costs involved and the clarity and certainty of the process. We might observe here that adjudication represents a familiar type of process for lawyer. Its premise is adversarial, based on a familiar model of written pleadings and results in a decision rendered by a third party adjudicator. As such it represents well-trodden terrain for lawyers and a fits hand in glove with their general modus operandi.

In stark contrast to the generally glowing reference provided by lawyers, consonant with anecdotal evidence of growing disquiet around the process, end-users were much more disparaging of adjudication. While joining hands with lawyers in their damning critique of arbitration and litigation, a mere $25 \%$ of end-users agreed that adjudication was generally fit for the needs of the construction industry. In follow up interviews, a wide range of reasons for dissatisfaction was voiced. Such complaints included, poor standards of adjudicators, the high costs of the process, limitations of the paper-based approach of adjudication and the ability of one side to highjack the other with a claim.

Despite these negative views, many end-user interviewees suggested, however, that the heavy presence of adjudication in the construction industry and its cultural embedding in the industry had the effect to squeeze out any potential for mediation to develop further in the field. In terms of this dominance, it should be recalled that lawyers may be crucial in developing cultural norms in dispute resolution. By dint of their oft powerful position relative to their clients in respect of dispute resolution decisions, lawyers may legitimise new processes by way of how they explain and evaluate such mechanisms to their clients - what has been termed "law talk" (Felstinar and Sarat, 1980-81). 
While lawyer dominance is certainly true in respect of disempowered, 'one-shotter' clients (Johnstone, 1972) it can be questioned whether this holds true in respect of more sophisticated repeat player clients, particularly in an era where lawyers have lost ground in terms of social status, and the financial squeeze on legal business may have rendered external lawyers more subservient to the demands of their clients.

In respect of the current research, the fact that the adjudication process may be one which comports better with the interests of lawyers rather than their clients, begs the question, however, as to the relative role of lawyers and their clients in decisions in respect of which dispute resolution pathways to take. On this question, survey evidence from our survey of end-users reveals that one of the most common reasons (40\%) as to why they had declined an offer from an opponent to mediate was that their lawyer had advised against it. Similarly, some $42 \%$ of end users viewed that lawyers acted as barriers to mediation's growth on the basis of their ignorance of the process and $43 \%$ blamed lawyers' negative perceptions of the process for their resistance. Such views are consistent with substantial evidence generally of lawyer resistance and cultural barriers towards mediation within legal circles globally and across different dispute areas (Peters, 2010; Clark 2012, Ch.2).

In respect of construction mediation Scotland, such viewpoints were given further credence in the qualitative research where many end user interviewees elaborated on the ways in which lawyers discouraged mediation and pushed other more traditional alternatives. Sentiments expressed included: "[1]awyers I've spoken to about mediation do tend to roll their eyes a little bit... There seems to be a bit of cynicism there. I guess it might be the thought that their clients are giving up some [or] ceding control of the project or the outcome a little bit...";

"[it's] for the lawyer to say, 'Well have you thought about mediation? Here's how it works, and it may just suit your particular dispute.' You don't get that kind of advice, in my experience I think the minute there's a dispute ... a subcontractor's first tendency is to go and speak to their lawyer, and then their lawyer starts writing letters, and then before you know it, it's adjudication or it's court."

Adding succour to the notion that lawyer resistance is a significant factor in stifling mediation in Scottish construction mediation circles were the views of lawyers themselves. First, interviews with lawyers found them espousing that they were typically in control of decisions relative to dispute disposal in construction matters even ultimately in respect of larger clients. The common sentiment expressed (also found in end-user interviews) was that once the matter escalated to the lawyers, they as experts hired by clients in need of their assistance, called the shots. If legal professionals do indeed harbour an inherent preference for the familiar shores of adjudication, the gatekeeping effect of lawyers to other processes may produce a very inclement climate for those interested in expediting mediation use. Similar evidence has been found in the context of commercial mediation in France by research undertaken by Borbelly (2011),

Lawyer disinterest may be predicated on a whole raft of reasons. As outlined at the outset of this paper, one such reason may be cultural dissonance. Unlike adjudication, mediation may seem a rather alien process to the lawyer with its emphasis on mutual interests, information sharing, harmony and client empowerment (Clark, 2012: chpt 2). The idea of mediation may thus render the process unappealing for lawyers particularly when yoked to a general ignorance of what mediating entails, concerns over losing control of the matter at hand as well as financial considerations that might lead lawyers to more potentially lucrative modes of dispute resolution (Clark, 2012: chpt 2). In all of this it has to be remembered that lawyers may have quite legitimate and genuine reasons for resisting the potential use of mediation in particular cases which we do not dispute. 
What is perhaps not surprising is that lawyer respondents did not generally lay the blame for the limited uptake of mediation in Scottish construction matters at the feet of the legal profession. In response to the statement that a barrier to mediation's development was its negative perception amongst lawyers, a mere 26 percent of lawyers surveyed agreed albeit that some of those interviewed reflected on the difficulties of persuading their legal colleagues to mediate. Lawyer respondents were in fact more likely to view that negative perceptions of construction industry professionals were a barrier to development (38 percent). Although end-users were much more likely than lawyers to blame legal professionals for poor uptake of mediation (e.g. caused by lawyers' ignorance $43 \%$; caused by lawyers' negativity towards the process, $42 \%$ ) they did not shirk from laying the blame at the door of their fellow construction professionals (caused by lack of awareness in the construction industry, $63 \%$; caused by negativity towards the process, $50 \%$ ). In this sense it could be argued that the well renowned machismo inherent within the construction industry may militate against the adoption of more conciliatory methods of dispute resolution such as mediation (Brooker and Wilkinson, 2012, p.3-4). While both lawyer and client respondents generally eschewed any notion that participation within mediation would be damaging to their reputation in the field (a mere $16 \%$ of clients and $8 \%$ of lawyers agreed with this statement) the interviewees for both groups revealed much more textured views on this matter. Many of those interviewed - both lawyers and end-users - pointed to the adversarial climate in construction law. Moreover, some end-users expressed the view that lawyers may be reluctant to propose mediation because their own clients would not like it. Certainly there has been significant debate surrounding the term 'mediation' itself. While mediation in practice may often amount to an arena of intense, tough negotiation, the current nomenclature may produce negative connotations such as weakness and compromise which would jar in 'hard-nosed' environments such as construction. Ross (2007) made the point a number of years ago that mediation in Scotland requires to be sold in a much more 'selfish' way pointing to individualistic gains that could be gleaned from the process - rather than the emphasis on harmony and compromise often prevalent at present. Certainly we view that such an approach may yield results in the context of Scottish construction.

\section{Conclusion}

The latter point above leads to a more general discussion about the future development of mediation in the Scottish construction sphere and the role of lawyers and end users within that. While there is evidence of a growing base of construction mediation in Scotland and seemingly real success in terms of the activity that has taken place, the overall level of use remains low. Coupled with growing dissatisfaction amongst the client base with adjudication and recent research in other jurisdictions pointing to significant financial benefits from mediating construction disputes (Gould et al 2009) the case for developing further use of the process is strong.

In terms of expediting mediation, a two-pronged attack is required. Although our evidence suggests that practical exposure is the best way to drive future commitment to mediation use, education has a key role to play too. It seems that lawyers remain largely in control of decisions to mediate, even perhaps in respect of large sophisticated players in the construction field. Quite rightly then educational efforts have often been targeted at the legal profession through increased exposure in university study and post qualifying level training. There is a small and growing cadre of lawyers that have become champions for the mediation process in Scotland (Clark, 2009) and we would expect this to continue to grow steadily. 
What is lacking, however, is sufficient awareness raising and education for the client base. In this sense the benefit of privacy in mediation may also be its worst enemy. Lack of dissemination of success stories relative to mediation is undoubtedly an inhibiting factor throughout the construction industry. To assist parties in crossing the Rubicon and dipping their toes in the waters of mediation, there needs to be greater education and training, and by involving government, professional institutions as well as mediation providers. There is a role for industry bodies such as the Royal Institute of Chartered Surveyors, the Institution of Civil Engineers, Scottish Building Federation and Chartered Institute of Arbitrators (Scottish Branch) through their training and CPD provisions to help propagate the mediation message to their members by educational measures focusing on the sharing of positive experiences gleaned in the process. In this sense, the most compelling cases for mediation are not to be made by mediators or other advocates of the process but by those who have themselves sampled its wares, are keen to go back for more and able to speak the language of other potential users in articulating its benefits. The research interviews we conducted with end users in particular revealed very powerful messages in this regard which may resonate well with industry peers.

\section{References}

Agapiou, A. and Clark, B. (2011) Scottish construction lawyers and mediation: an investigation into attitudes and experiences, International Journal of Law in the Built Environment, Vol. 3, No. 2.

Agapiou, A and Clark, B (2012) An empirical analysis of Scottish Construction Lawyers' interaction with mediation: a qualitative approach, Civil Justice Quarterly, Vol 31, No. 4, pp. 494-513

Agapiou, A and Clark, B (2013) A follow up empirical analysis of Scottish construction clients interaction with mediation, Civil Justice Quarterly Vol 32, No. 3

Borbelly, A (2011) Agency in Conflict Resolution as a Manager-Lawyer Issue: Theory and Implications for Research. Negotiation and Conflict Management Research Vol4, Issue 2 pp 129-144

Brooker, P. and Wilkinson, S. (Eds) (2010), Mediation in the Construction Industry: An International Review, Spon Press, London.

Burns, M (2012) Should Mediators Be Experts in the Subject Matter of the Disputes available at http://www.resm.co.za/should-mediators-be-experts-in-the-subject-matter-of-disputes/

Clark, B. and Dawson, C. (2007) Scottish Commercial Lawyers and ADR: Awareness, Attitudes and Experience. Civil Justice Quarterly, Vol 26, No. April, pp. 228-249

Clark, B. (2009) Mediation and Scots Lawyers: Past, Present and Future, May, Edinburgh Law Review. Vol 13, No. 2, pp. 252-277

Clark, B. (2012) Lawyers and Mediation, Springer, Berlin/New York

Dundas, H. and Bartos, D (2010) Arbitration (Scotland) Act 2010, W. Green, Edinburgh

Felstiner, W and Sarat, A (190/81). The Emergence and Transformation of Disputes:

Naming, Blaming, Claiming, 15, Law and Society Review 631.

Geertz, C (1973) The interpretation of cultures. New York: Basic. $476 \mathrm{p}$

Genn, H. (2009), Judging Civil Justice, CUP, London. 
Gould, N. (1999) Dispute resolution in the UK construction industry — processes, perceptions and predictions. The International Construction Law Review, Vol 16, No. 4, pp. $574-587$

Gould et al., (2010) Mediating Construction Disputes: An Evaluation of Existing Practice. Kings College London, Centre of Construction Law and Dispute Resolution (London)

Johnson, T (1972) Professions and Power. London: Macmillan.

Latham, M (1994) Constructing the team: final report - Joint Review of Procurement and Contractual Arrangements in the United Kingdom, Construction Industry, HMSO

Peters, D. (2010) It Takes Two To Tango, and Two To Mediate: Legal, Cultural and Other Factors Influencing United States and Latin American Lawyers; Resistance to Mediating Commercial Disputes, Rich. J. Global Law and Business. Vol 9, pp. 381-429

Reich, J Brad (2002) Attorney v Client: Creating a Mechanism to Address Competing Process Interests in Lawyer-Driven Mediation, 26 Southern Illinois University Law Journal 183.

Ross, M (2007) Mediation in Scotland: An Elusive Opportunity? in: Global Trends in Mediation (2nd Edition); Alexander, N (Ed), Kluwer Law International

Sela, A. (2009) Attorneys 'perspectives of mediation: an empirical analysis of attorneys 'mediation referral practices, barriers and potential agency problems, and their effect on mediation in Israel (doctoral dissertation, Stanford university).

Wissler, Roselle (2003) Barriers to Attorneys' Discussion and Use of ADR, Dispute Resolution Magazine, Vol. 10, p. 27, Available at SSRN: http://ssrn.com/abstract=1723250

Welsh, Nancy A (2004) Stepping back through the looking glass; real consultations with real disputants about institutionalized mediation and its value, 19, OHIO ST J, ON DISP RESOL, 573 